\title{
Debating Racism During Initial Teacher Education: A Case Among Chemistry Students
}

\author{
Wilmo Ernesto Francisco Junior ${ }^{1}$ and Erasmo Moises dos Santos Silva ${ }^{2}$ \\ ${ }^{1}$ Federal University of Alagoas, Brazil \\ ${ }^{2}$ State Department of Education of Mato Grosso, Brazil
}

\begin{abstract}
Discussions on racism in classrooms pose a huge educational challenge today, since racism has become naturalized within society, and racial issues are rarely addressed in science teacher education courses. Considering the social problems originated from racism, this paper discusses some aspects of them through a dialogical activity conducted among students in a chemistry teacher-training course. In order to engage the students in the dialogue, a poem that enable discussing social and scientific issues was chosen and had been set to music. At the first part of the discussion, only one student took the poem's key message as referring to racism. This seems to be directly related to the poor discussion of this topic within society. Through interactive discourse characterized by integrated transition between dialogic and authoritative communicative approaches, a common viewpoint about racism was achieved by all participants, including students who had not identified the matter in the poem initially. Although isolated activities are not enough to consistently develop teachers' beliefs and attitudes against racism, the findings suggest that discursive movement can encourage critical thinking about this.
\end{abstract}

Keywords: dialogue; poem; racism; chemistry teacher education.

\section{Contextualizing the problem}

In January 2013, the president of Brazil sanctioned law 10,639, which established that teaching of African history and culture at public and private institutions during basic schooling would be needed. The background to this was a debate regarding the importance of and the need for fully-critical comprehension of the construction of Brazilian society and the historical difficulties faced by African descendants caused by low appreciation of their culture and phenotypic features. Underestimation of African cultural features is a consequence of hundreds of years in expropriation of African values, and extermination of a race that was considered "inferior" for a long time (Andrews, 1992; Graham, 1999; Hasenbalg \& Valle Silva, 1999; Ianni, 1972; Kagema, 2018). According to Paulo Freire (2005a, p. 25-26):

One of the key features of the domination process, by means of colonization oppression or sexist/class domination, is the need that the ruler has to culturally invade those who are dominated. Therefore, a cultural invasion is fundamental, because it uses power, through violent, tactical methods or through fraudulent methods. The goal of cultural invasion is, among other things, to destroy, which fortunately does not prosper in concrete terms. It is essential for the dominator to grind the cultural identity of the dominated. And when we take a look at the experiences of colonized countries, including Brazil, we see the barbarity, the dispute, the settler behavior.

Consequently, educational opportunities and opportunities within life have been quite different among black and white people in Brazil (Andrews, 2009; Cerqueira \& Moura, 2014; Hasenbalg, 1985; Hasenbalg \& Valle Silva, 1999; Theodoro \& Jaccoud, 2005). This culturally-situated hegemony of black inferiority leads to barriers that African Brazilian students and their teachers need to navigate through, which implies in developing didactic proposals that enable comprehension and make it possible to surmount the social injustice.

In order to contribute towards this theoretical-methodological undertaking, the present study provides reflections regarding the comprehension needed of this situation. This paper is divided into two parts. Firstly, it is presented the construction of the ideology of black inferiority based on some historical aspects, along with the role of the formal schooling process. Secondly, it is presented an investigation conducted among chemistry students engaged on discussing racism. 


\section{The social construction of black inferiority and the role of the schooling process}

A study based on official statistics (Cerqueira \& Moura, 2014) of the social characteristics of African descendants and White people in Brazil revealed significant differences in terms of income, education and living conditions. Concerning to violence, for each non-black homicide in Brazil, 2.4 black people were murdered. The same study pointed out that among the poorest people in Brazil, $11 \%$ were black but only 5\% were white. Data from the Brazilian Institute for Geography and Statistics (Theodoro \& Jaccoud, 2005) indicated that the black population's per capita income was less than half of the white population. A study conducted in the city of São Paulo, Brazil, showed that Afro-Brazilian men earned 58 percent of white men's income (Andrews, 2009). Regarding education, in the 2024 age group, $53.6 \%$ of young white adults were enrolled at universities, whereas for blacks this figure was $15.8 \%$ (Theodoro \& Jaccoud, 2005).

The reasons for this contrast are interwoven in different ways. A historical analysis about the black people situation in Brazil reveals two dimensions: i) the racist ideology and atrocities of the enslavement process; ii) the consequent projection and dissemination of social inequalities to the present times. In Brazil, the introduction of the slavery system to meet the demands of European colonizers was crucial in strengthening social inequalities, especially between African and European descendants (Graham, 1999; James, 2018; Hasenbalg \& Valle Silva, 1999). Wade $(2010$, p. 8$)$ states that "certain races became defined as non-rational or esthetically inferior (lacking in 'natural' balance of beauty and harmony) and race could define certain people as fit for slavery".

Since then, the cultural and phenotypic characteristics of black people have been undervalued, and negative attitudes towards the physical features of black women and men are frequently reported (Andrews, 1992; Hanchard, 1999). Standards of beauty mostly relate to straight hair, to the detriment of curly hair; and to blue and green eyes, to the detriment of brown eyes. Ani (2007) underscores that these processes seek to convert people who were originally from different cultures to a world based on European patterns.

Beyond the cultural depreciation during the enslavement process, the consequent extension of discriminatory stances in the $19^{\text {th }}$ and $20^{\text {th }}$ centuries reinforced the social segregation of black people. Afro-Brazilians were excluded from employment opportunities and other preferences, granted preferentially to European immigrants, being also apart of the right to vote and of other forms of political participation (Andrews, 1992). Additionally, in the first decades of the $20^{\text {th }}$ century, the phenotypic view of inferiority was strengthened through science. Attempts were made using scientific studies towards establishing that Africans were biologically inferior beings (Santos, Schucman \& Martins, 2012). This was the age of scientific racism and researches along these lines were conducted in different areas of knowledge and countries (Wade, 2010). Nowadays, however, even though the human genome presents discrete variations (Wade, 2010), biological racial distinctions cannot be reliably measured and scientifically accepted in order to explain criminality, intelligence or any kind of social behavior and intellectual skills. Nonetheless, even if race has no biological importance, racism as a social problem is real.

In Brazil, the myth of racial democracy is a further implication of unequal relationships caused by racism. This myth suggests that: i) there is a peaceful coexistence among people of different ethnic-racial origins; ii) Brazilian people are not white, black or indigenous, but only one mixed-race combination. This myth was consolidated by the Brazilian sociologist Gilberto Freyre, who stated that Brazil benefited from race miscegenation, since it solved the problems of race relations.

Brazil stands today as a community from whose experiment in miscegenation other communities may profit. Probably in no other complex modern community there are problems of race relations being solved in a more democratic or Christian way than in Portuguese America. And Brazil's experiment does not indicate that miscegenation leads to degeneration. (Freyre, 1951, p. 98-99).

However, this is a naive view that implicitly carries a biased position. Indeed, the process of mixing is very complex and can be seen as progressive whitening of the population. Miscegenation would supposedly bring about elimination of blacks and indigenous people and creation of a mixed-race society that would be at the distinctly whiter end of the spectrum - in terms of color and culturally (Andrews, 2009). Thus, in Brazil, there was an explicit endeavor to mold an identity that would come closer to a European identity, as can be seen in another quotation from Gilberto Freyre: "Negroes are now rapidly disappearing in Brazil, merging into the white stock" (Freyre, 1951, p. 96). According to Wade (2010), the emergence of a mixed-race society was integrationist in tone, in which black input was valued inasmuch as it was under control. 
These conceptions have been prejudicial for the construction of a positive identity for Brazilian black people. Considering that identity relates to acceptance of cultural and phenotypic origins, miscegenation denies or hides the influences from Africa in Brazilian society. In this way, identity and personhood became increasingly defined by a discourse of race (Wade, 2010). If certain races were defined as inferior, people would not recognize themselves as such, as it would imply in accepting their inferiority. Hence, racism as a social problem tends to be denied, sometimes by Afro-descendants themselves in order to avoid presumed inferiority. Consequently, inexistence of racism has been consolidated into the Brazilian social imaginary, and this belief hinders attempts to discuss ethnic-racial relations in schools.

All these historical factors intertwined have contributed towards the social differences between black and white Brazilians mentioned earlier. For those reasons, the present study takes race to be a social and historical construct built on phenotypic variations. Accordingly, racism can be seen as the use of disparities in physical appearance to classify, hierarchize, include and exclude people in a variety of ways. In societies that went through long periods of slavery (Brazil was the last country in the Americas to officially abolish enslavement), vestiges of these categories remain socially evident. Valente (2016) demonstrates a relationship between race and access to higher education. The author reports a vicious circle which connects the schooling of the young with their race, socio-economic status and university attendance.

In this context, educational institutions have a pivotal role in unmasking the myth of racial democracy through delving into the roots of oppression relationships, and by evenhandedly exploring the knowledge, culture and world views that comprise the heterogeneity of Brazil (Silva \& Francisco Junior, 2018). Verrangia and Silva (2010) state that formal education provides a favorable environment for promotion of positive ethnic-racial relations because of the remarkable diversity of the students. Therefore, the significance of schools as institutions that are committed towards active citizenship increases the need for discussions on ethnic-racial issues in teacher training courses (Delpit, 1995). In this perspective, teachers' beliefs and attitudes in pursuing this discussion are important to provide or not the academic progress of Black students. Recent researches displayed different degrees of race consciousness and expectancies reinforcing ideologies and material conditions associated with the racial aspects (Cherng, 2017; Liou \& Rojas, 2018). For Lewis (2016), unconscious forms of anti-oppressive education miss the centrality and thus do not go far enough in uncovering the embodied, perceptual roots of racism. On the other side, a culturally responsive positive would make difference in anti-racist education.

Given the social problems from racism and the role of the schooling process in reproducing or masking inequalities, educational programs need to prepare teacher candidates who are culturally and ethnically aware, so that new teachers can foster academic success through developing curricula and effective teaching methods for diverse student populations (Johnson \& Hinton, 2019; Mitran, 2017; Tarman, 2012). According to O'Loughlin (1992), teachers should be trained to develop critical views of social and multicultural contexts (Byker \& Marquardt, 2016). However, Marom (2017) argues that under the cloak of professionalism the colonial assumptions still remained at the core of teacher education. In turn, Kishimoto (2016) points out that anti-racist pedagogy is an organizing effort for institutional and social change that is much broader than teaching in the classroom. There are three components for this line of action: (1) incorporating the topics of race and inequality into course content, (2) teaching from an anti-racist pedagogical approach, and (3) anti-racist organizing within the campus and linking our efforts to the surrounding community.

In this regard, Paulo Freire's critical views may be useful in discussions regarding teacher education. Freire (1998, 2005b) outlined the notion of praxis, which views critical inquiry as reflecting and acting on the world to transform it. As Freire (2005b, p. 72) wrote, "knowledge emerges only through invention and reinvention, through the restless, impatient, continuing, hopeful inquiry that humans pursue in the world, with the world, and with each other". In his view, education is essentially a humanistic, historical and continuing process.

Paulo Freire conceived a set of values that characterize humanity and regard knowledge as a product of human practices for transforming the world. Humans are considered beings of praxis who emerge from the world and are capable of objectifying it. In so doing, they can understand it and transform it by means of labor. As historical beings, people know that they are unfinished; they are aware of their incompletion. This incompletion and this awareness depend on the very roots of education as an exclusively human manifestation (Freire, 2005b, 2008). Thus, education can be continuously reconstructed in praxis: "reflection and action upon the world in order to transform it" (Freire, 2005b, p. 51).

As this happens, words take on new power. They are no longer an abstraction but a means through which people discover themselves and their potential in the world. To educate is essentially to shape people's minds, through addressing their attitudes and capacity for criticism. Such a stance includes critical thought, tolerance, agency, dialogue and respect for the importance of difference. Dialogue emerges as another fundamental principle of Freire's pedagogy. Freire (2005b) stated that it was impossible to educate regarding critical consciousness outside of the dialectic process, which involves dialogue among individuals. 
In this light, the present study reports on a research activity in which the main goal was to foster reflections among future chemistry teachers regarding racism within a dialogical environment. To promote this discussion, a poem set to music was used, followed by a dialogical discussion. The central question of this study was: "What discourse interactions are produced and how do these interactions relate to perceptions and formation of meaning regarding ethnic-racial issues?"

\section{Methodology}

\section{Research Design}

This study has exploratory-interpretive design based on qualitative methods. The aim of this methodological approach is to investigate a contemporary phenomenon in depth and with focus on description, interpretation and identification of possible patterns in the form of themes (Bogdan \& Biklen, 1998). Thus, this study involved seeking to more deeply understand certain aspects of a specific real context. This context was a chemistry teacher training course and the phenomenon was a debate about racism.

As presented earlier, racism is a social problem in Brazilian society and approaches towards this in classrooms can be considered a huge educational challenge. In addition to this, such discussion during chemistry teacher training at the university in question was scarce. There were no specific disciplines in the regular curricular program or extracurricular activities regarding racism. Given that studying African history and its contributions towards Brazilian society is now mandatory, an extracurricular activity was designed for involving students in such discussions.

\section{Context and participants}

The study was designed based on a dialogue that focused on racism. This dialogue was conducted by a black male university professor who had proven experience in multicultural education and dialogic education. The participants in this study were 21 prospective chemistry teachers (7 males and 14 females; of whom three were black) from a Brazilian federal university who represented $20 \%$ of regular students enrolled in the course. The students were attending the fifth to the seventh phases of their undergraduate course by the time of the activity (the regular course lasts eight phases, or four years). Their ages ranged from 19 to 24 years old. This group had not yet studied aspects of multicultural education, African history and culture or racism in the formal higher education curricula.

The activity was developed and scheduled as an extra-class activity that aimed at discussing social questions related to chemical education or education in general. Participation was voluntary. The activity was structured on the presentation of poem that had been set to music in order to engage the students in the debate. The poem chosen is named "A black woman's tears" (Figure 1), written by Antonio Gedeão, which is the nom de plume of Rómulo Vasco da Gama de Carvalho, a Portuguese poet and physical chemist, who also wrote on history of science. The poem was chosen because of its social and scientific characteristics, which enabled discussion of a variety of issues. Firstly, the poem was distributed to the participants and then the song was played twice.

\begin{tabular}{|c|c|}
\hline \multicolumn{2}{|c|}{ A black woman's tears } \\
\hline $\begin{array}{l}\text { I found a black woman } \\
\text { who was crying, } \\
\text { I asked her a tear } \\
\text { To analyze.. }\end{array}$ & $\begin{array}{l}\text { I extracted it with acids, } \\
\text { with alkalis, and salts, } \\
\text { and such substances as used } \\
\text { in these cases. }\end{array}$ \\
\hline $\begin{array}{l}\text { I collected tears } \\
\text { (taking utmost care) } \\
\text { in a test tube } \\
\text { properly sterilized. }\end{array}$ & $\begin{array}{l}\text { Probed in low temperatures, } \\
\text { and lit with fire, } \\
\text { it gave the same result } \\
\text { every time: }\end{array}$ \\
\hline $\begin{array}{l}\text { I observed it from one side } \\
\text { to the other, and in front: } \\
\text { it seemed just a drop } \\
\text { of very clear air. }\end{array}$ & $\begin{array}{l}\text { Neither blackness } \\
\text { nor traces of hate were found, } \\
\text { almost only purely water } \\
\text { and sodium chloride. }\end{array}$ \\
\hline
\end{tabular}

Figure 1. Poem A Black Woman's Tears by António Gedeão. Extracted and translated from: Silva (2011) 
To start the debate, a discussion about the central theme of the poem was put forward. In terms of the teaching purposes, the debate was divided into four parts: i) exploration of students' perceptions about the poem and ideas regarding racism; ii) discussion and comparison of ideas; iii) summarization of possible interpretations; and iv) enlargement of points of view through presentation of new arguments. Each of these parts consists of episodes used for analysis.

\subsection{Data collection and analysis}

A video recording of the debate was combined with field notes taken during the activity, in order to gather not only the students' verbal interactions but also their expressions and behaviors. The field observations were made based on the participants' attitudes and emotions. The video recording was conducted by a collaborator and the field notes were taken by the authors of this paper (whom had a $\mathrm{PhD}$ in science education and more than ten years of experience in qualitative research and the other who, in the occasion, was developing an undergraduate research project). Data collected through different methods were cross-checked to achieve better reliability regarding the students' actions and perceptions during the debate.

All the video-recorded debate was transcribed and subsequently analyzed based on an analytical tool developed by Mortimer and Scott (2003). The analysis on the discursive interactions was performed independently by the two researchers, who discussed and reviewed the interpretation to assure greater reliability.

This analytical framework took into consideration three main issues: teaching purposes, interaction patterns and communicative approach. These aspects can be divided into others, as illustrated in Table 1.

Table 1.

Aspects of the analyses on discursive interactions

\begin{tabular}{lll}
\hline I. Teaching purposes & 1. Teacher's intentions & 2. Topic \\
II. Approach & 3. Communicative approach & \\
III. Actions & 4. Interaction patterns & 5. Teacher interventions \\
\hline
\end{tabular}

Source: Mortimer \& Scott (2003)

The second aspect of the analysis refers to the interaction patterns emerged between the teacher and the students during the ongoing classroom debate, taking into consideration four interaction patterns (Aguiar, Mortimer \& Scott, 2010):

1) A traditional I-R-E pattern, normally started with a question presented by the teacher (I), followed by a student's response $(\mathrm{R})$ and a teacher's evaluation $(\mathrm{E})$.

2) A closed chain of interactions of the type I-R-P-R-P-R . . E, started by the teacher and generating different student's responses followed by the teacher's promptings $(\mathrm{P})$, which has the goal of producing further responses. The sequence ends with an evaluation from the teacher.

3) An open chain, identical to the preceding pattern, but without a final teacher's evaluation.

4) A question-and-answer pattern, in which questions from students are followed by teacher's answers.

In terms of a communicative approach, Mortimer and Scott (2003) presented four fundamental categories for utterances emerged on discussions among teachers and students based on two dimensions. The first one includes a continuum between dialogical and authoritative discourses. The second involves interactive and non-interactive talks.

Combinations of these dimensions generated four classes of communicative approach: 1) interactive/dialogical; 2) non-interactive/dialogical; 3) interactive/authoritative; 4) non-interactive/authoritative. Interactive and non-interactive refer respectively to the participation of more than one person or by solely one (usually the teacher) during an ongoing classroom discourse. In dialogical discourse, there are openings to different points of view about the issue under discussion, whereas in authoritative communication, the focus is on just one perspective and, therefore, there is no exploration of different ideas.

In addition, the outcomes were analyzed in relation to previous studies on racism and education, as well as in relation to Paulo Freire's thoughts.

\section{Results}

As stated earlier, the debate was grounded on the lyrics of the musicalized poem. All the students participated actively during the presentation of the song. The students asked whether it would be played again, so that they could sing along. This probably related to the role of art in dealing with esthetics and ideas of beauty, feelings, imagination and values, combined within affective appeal, provoking special feelings of pleasure (Galili, 2013). The feelings and the discussion would probably not have been the same if the debate had been started without the musical item. 
Therefore, it is fair to assume that the musical presentation gives rise to a pleasurable situation from which the ongoing didactic activity could be started.

The results are divided into four episodes that each represents a specific aim. The outcomes presented do not contain all the verbal interactions, but they sequentially follow the main ideas emerged through the debate. Only three students had no verbal manifestation during the activity.

\section{Episode 1 - Exploring students' ideas}

After the music had been played, the professor invited the students to think further about the poem. The first teaching purpose was to engage the students in a collective discussion. It was his aim as well to to explore the students' interpretations of the poem and their ideas about racism.

This first episode lasted 11'20", and five students manifested their opinions through talkings. During this period, most of the students were concentrating on the discussion and demonstrated their attention by looking directly at the speakers. Occasionally, some students looked at the poem, apparently trying to analyze the verses. During the first five minutes, two students at the back of the room seemed to be distracted by something on their laptops. In general, the students demonstrated engagement in the discussion, which was the initial aim in episode 1 (Figure 2).

The teacher spoke for a total time of 3'51', while the students talked for 2' $55^{\prime \prime}$ '. The students mostly discussed the issue of the poem, and discordances were observed. This was an interactive and dialogical episode in which the professor asked the students to share their ideas about the poem. After the professor's questions, the discussion became dialogical and interactive, with the aim of exploring the students' ideas. Therefore, the sequence of interactions could be characterized as I-R-P-R-P-R... (open-chain pattern: initiation-response-prompting-response-prompting, with no teacher's evaluations), since there has been always a prompt following each answer. From speaking turn no. 12 onwards, the discussion proceeded exclusively among the students, based, therefore, on the interactive perspective.

Verbal interactions allow transitions between individual and social planes in classroom, thereby providing the means for individual thinking. Hence, the process is not seen as reception and repetition. Interactive and dialogical discourse opens different viewpoints about the issue under discussion (Mortimer \& Scott, 2003). Moreover, it is only through social interaction and participation in cultural life that oppressive conditions can be questioned.

1. Teacher: Firstly, I would like to listen to your comments on the poem that you have in your hands. What do you think about it? Any doubts, questions or unknown words? Would anyone like to ask anything? Anyone? (After a while with no response)

2. Student A: Why is the poem's title "A black woman's tears"?

3. Teacher: Why? This is an interesting question, isn't it? Why "A black woman's tears"? What do you think?

(No one answers, and the teacher continues). What is the author's message?

(New silence)

4. Student C: I think the author is talking about racism.

5. Teacher: She said that the author was referring to racism. Could anyone add anything? Do you think the main theme might be racism?

6. Student D: No.

7. Teacher: And then, what it would be?

8. Student D: The author took a tear... and analyzed it.

9. Teacher: He took it and made an analysis.

10. Student D: And he concluded that the tear was made of water and sodium chloride.

11. Teacher: It was water and sodium chloride...

12. Student C: And that would be the tears of a black woman.

13. Student D: In fact, he didn't say that the tear was from a black woman.

14. Student C: (something inaudible)

15. Student D: That black would refer to...

16. Student C: A black person.

17. Student D: No, it could be said affectionately. Like, you have a girlfriend and call her my little black (laughs), not because she is black...

18. Student A: I am a black person (laughs) and...

19. Student E: I also cannot identify...

20. Student D: I think that it has nothing to do with racism.

21. Student E: I also cannot identify any references to racism, I cannot identify any. I also think that black is a concept he used as a...

22. Student D: In affectionate way.

23. Student E: I don't know if it was affectionately, but maybe... just to refer to that person. 
Figure 2. Transcription of episode 1: Exploring students' ideas

In the first episode, the interactions allowed the emergence of different points of view, in which students C, $\mathrm{D}$ and $\mathrm{E}$ each defended their interpretations. This part of the discussion presents an interesting aspect. The only student to initially defend the idea of racism was a black woman (student C). Her colleagues rejected the interpretation that racism was the reason for the woman's tears reported in the poem. This denial showed how non-perception of racism is intrinsic to society and how people's inertia regarding racist attitudes has become naturalized. According to Silva (2011, p. 76):

It is important to remember that the action of educating is the conjugation of teaching and learning acts. What can be "taught" is only that which has been learnt. Consequently, those who have been educated in a racist environment characterized by discrimination tend to transmit this experience, the way of relating to others who they consider to be inferior in light of their preconceived ideas.

Malone and Barabino (2009) describe how ethnic minority students reported feeling isolated and marginalized within science classrooms. Brickhouse and Potter (2001, p. 965) argue that, for young women of color, "the experience of marginalization can make membership in a school science community impossible or undesirable". In this regard, adopting a posture of being inert to manifestations of racism is to be on the dangerous side of a thin border that separates people who behave indifferently in racist situations and those who have racist feelings, discourse and actions.

Freire (2005b) stated that the dialectic process involving dialogue among individuals is important for critical consciousness. In his view, men and women would be educated by each other, mediated by the world and by means of dialogue, which would pose itself as a tool of humanization. Words would not be a mere expression of thought; they would be the transformation of praxis.

If it is in speaking their word that people, by naming the world, transform it, dialogue imposes itself as the way by which they achieve significance as human beings. Dialogue is thus an existential necessity. And since dialogue is the encounter in which the united reflection and action of the dialoguers are addressed to the world which is to be transformed and humanized, this dialogue cannot be reduced to the act of one person's "depositing" ideas in another, nor can it be become a simple exchange of ideas to be "consumed" by the discussants. (Freire, 2005b, p. 88)

In Freire's proposition, people would meet in cooperation to transform the world. In such situations, the dialogical process would focus on realities that, when set as a problem, challenge people. The dialogical process would be rooted dialectically, and one thing would not annul the other. In this perspective, it is fundamental to struggle against any standstill in order to overcome racism.

Ambe (2006) advocates that teachers training institutions have the responsibility to provide future professionals with the skills necessary for meeting the intellectual, social and personal needs of diverse learners. For this reason, recognition would be the first step towards addressing actions against discriminatory stances. Teachers who operates with a higher degree of race consciousness are capable of more equitable teaching practices that emphasize self-respect, solidarity, and education as a collective contract for the common good (Liou \& Rojas, 2018). Thus, according to Freire, educational practice would need to aim towards changing the context of alienation and, consequently, of oppression, which would then enable people to reflect by themselves on their responsibility and role in anti-racist attitudes.

\subsection{Episode 2 - Comparing ideas}

Proceeding with the discussion, the teacher wanted to deepen the debate through the students' ideas. The duration of this episode was 8'02'. The professor spoke for 5'17' and the students for 2'39'. Although few students contributed at the collective discussion during this period, many of them were debating the issues with each other. Each utterance among the students was short but significant. They seemed to be discussing their interpretations regarding the debate, considering the way in which they were talking, pointing at the sheet (the poem) and then turning their attention to the rest of the discussion. Some students also took notes. 
The purpose of this episode was to get an agreement on the possible interpretations of the poem's main theme. With this aim, the professor focused on specific verses in order to employ critical analysis based on hypothetical and deductive thinking, as it is shown on Figure 3.

The initial questions had the aim of stimulating the students to share their opinions. Therefore, this fragment is also interactive, with an open-chain pattern I-R-P-R-P..., for the purpose of prompting contributions to promote hypothetical thinking. This episode also presented dialogic characteristics, because different interpretations from students can be seen. At the same time, the professor was stressing some verses for stimulating another point of view (What is the relationship between blackness and traces of hate?).

In this regard, dialogue can be characterized as an important apparatus for modification of worldviews. Silva (2011, p. 76) argues that:

In order to learn, it is necessary to interact, to express one's opinion, to reconsider ideas, to evaluate positions, postures and attitudes, to make an effort to understand points of view different from one's own and to work at de-constructing preconceived notions. In order to learn, it is necessary to become aware of both the realities in which we live and those of others with whom we are learning.

1. Professor: What would the main theme be, then? And the careful analysis, what do you think it refers to?

2. Student D: Depicting a chemical analysis through the poem.

3. Professor: Depicting a chemical analysis through the poem. Does anyone have anything else to add? Anyone? (Pause) So we have two interpretations, the first one gives emphasis to a chemist's work, and the other points out to a social issue relating to racism. (Pause). Would anyone like to add anything else?

4. Student G: I think there is a correlation between these two ideas when he says "traces of hate", so I guess she had some sort of feeling that made her cry. On the other hand, there is a part about a chemist who analyzes this tear and says it is made of water and sodium chloride, so I think there is a correlation between the two ideas.

5. Professor: Our colleague G argues that there's a correlation between the two ideas. When we think about the development of both science and the arts, one way to gain a better understanding is to consider the historical context. So, what would bring the author to write something like that? Firstly, our colleague said that the author has a background in chemistry, which leads to the scientific aspect of the text, and the other issue is the social one that surrounds us as well, so let's keep analyzing. Well, the scientist requested a tear. Tears are a typical human trait. After the whole process that he describes, it gave a usual result. All this means that sometimes it was repeated a few times. "Neither blackness nor traces of hate". Those are two interesting lines for us to think about. But I would like you to talk more about this. Could anyone comment on this? What is the relationship between blackness and traces of hate? What can you take, interpret or infer from this?

6. Student A: From his analysis, he could not find even a sign to indicate that the woman was black, white or yellow. Through her tears, the woman's race could not be inferred.

7. Student G: He wanted to show that we are all equal, independent of color.

8. Professor: What else? The result was always the same. But by describing "Black and traces of hate"? Does it relate to the woman's crying? Could it be?

9. Student C: It is not possible to affirm for sure.

10. Student D: I also think it remains unclear.

Figure 3. Transcription of the episode 2: Comparing ideas

Given that, student D put forward several possibilities for the woman's tears, the professor brought up scientific issues so that the students would become aware of, as in science as in art, it is necessary to test assumptions (Bicak \& Bicak, 1988). In speaking turn no. 5, the professor's utterance was based on a more structured view, which considered a historical perspective (one way to achieve a better understanding of a subject is to consider its historical context). In working on students' ideas, the communication approach adopted was interactive/authoritative. In this approach, teachers usually select some viewpoints and discount others, marking key ideas to be explored (Mortimer \& Scott, 2003). The professor's discursive approach can be understood in this context considering how he encouraged the development of a specific content supported by a scientific perspective.

At the end of the speaking turn no. 5, the communicative approach observed was once again interactive and dialogical, in which the aim was to elicit participation among the students (I would like you to talk more about this. Could anyone comment on this?). This is an ongoing process of comparing, checking and fostering different 
understandings. Most of the students' first reading of the poem indicated a common-sense perspective. In a dialogical process, the challenge is to develop convincing arguments in order to provoke engagement and interaction. So, a main characteristic of a dialogue is to maintain ideas on a social plane, which involves a dynamic dialectical movement between "doing" and "reflecting on doing".

Additionally, dialogue allows to reinforce students' identities and life experiences. A fundamental challenge is the way students' histories, perspectives, and life experiences can be used to overcome white norms. Ladson-Billings (2014) highlights the importance of using it as an anti-deficit pedagogy.

\subsection{Episode 3 - Summarizing possible interpretations}

This episode was the shortest one (4'54') and there were a few moments of silence. Four students participated on this part of the discussion, with a duration of 2'15', while the professor's discourse lasted 2'31'. The first speaking turn was the longest, followed by immediate interactions. The students were attentive and did not talk to each other. From speaking turn no. 4 onwards, the students' participation became enhanced.

After the professor had highlighted some verses and had tried to establish a correlation between blackness and traces of hate, the dialogue was directed towards the reason why the woman was crying and on plausible hypotheses for the correlation cited before. The discourse revealed that the students achieved a common interpretation and agreed with each other. However, divergences were also present. The interaction pattern was predominantly I-R-P-R-E..., taking into consideration that the professor's questions aimed at evaluating the students' propositions in order to corroborate his ideas. From the consensus, the professor used discourse and voice intonations to emphasize an interpretation regarding racism. Consequently, in this episode, more students expressed concordance, including student $\mathrm{D}$, as can be seen in Figure 4.

1. Professor: We cannot be sure. However, if someone is crying, it may be for two reasons. Either she is crying because of happiness, or it's because of some kind of pain. Moreover, this pain can be either a physical pain or an emotional pain. We need to think about these hypotheses.

2. Student A: But if no hate was found, what would be the reason?

3. Professor: Let's see. We can divide this poem into three parts. First: someone meets a woman who is crying and collects a tear from her. Second: a chemical analysis is made on that tear. Third: the result, which was no blackness or traces of hate. What does "blackness and traces of hate" mean? Could it refer to the reason why the woman was crying?

4. Student H: I agree with this relationship.

5. Student G: It may be related to exploitation of blacks (pause). And even with this exploitation, she has no traces of hate.

6. Professor: Any exploitation or any act that she suffered, which left her crying, but no traces of hate remaining. Could it be an interpretation?

7. Student D: I think it could be!

8. Student H: And look at the poem's title: "A black woman's tears." So, she is certainly a black person.

9. Professor: So, let's think a bit more about this. She was crying and this may have been for any reason. However, the poem portrays a chemical analysis on the tears. The tests demonstrated that neither blackness nor anything hateful was present. I guess we can associate the crying with something related to racism. Is it a plausible hypothesis? What do you think? Student D, what do you think?

10. Student D: Yes, it can be interpreted like that.

11. Professor: It would be consistent with the poem, wouldn't it?

12. Student G: I think so.

13. Professor: And what about the chemical analysis on the tear? How does it come into play in our interpretation?

Student L: The result was always the same. It may mean that the author had already analyzed other tears and the tears of the black person were similar to these others; there was no difference.

Figure 4. Episode 3: Summarizing possible interpretations

Although student D had been reluctant, the dialogical and critical movement through which the professor presented hypothetical and deductive thinking, aiming to promote a rereading of the poem's message, led the student to consider racism as a possible interpretation. Thus, the process of co-participation played a fundamental role in evoking thoughts and modifying them. In terms of our analytical framework, the utterances were authoritative and interactive. This stance is likely to be useful in maintaining students' engagement in teaching purposes, since it is based on a collective approach. According to Freire's perspective: 
In this sense, to teach right thinking is not something that is simply spoken of or an experience that is merely described. But something that is done and lived while it is being spoken of, as if the doing and living of it constituted a kind of irrefutable witness of its truth. To think correctly implies the existence of subjects whose thinking is mediated by objects that provoke and modify the thinking subject. Thinking correctly is, in other words, not an isolated act or something to draw near in isolation but an act of communication. For this reason, there is no right thinking without understanding, and this understanding, from a correct thinking point of view, is not something transferred but something that belongs essentially to the process of coparticipation (Freire, 1998, p. 42).

The ethical, political and cultural issues in science classrooms are very complex and require science teacher's educators to work together aiming to promote multicultural education along science teacher training programs. Thus, teaching cannot happen apart of social activism, and acceptance that racism exists is the first step on a long journey that demands enlargement of knowledge, beliefs and attitudes.

As mentioned earlier, in taking a problem-posing stance, students are no longer docile listeners, but are now critical co-investigators dialoguing with the teacher. Tensions were clearly observed during the poem's discussion. There are different communicative approaches guiding changes in concepts relating to ethnic-racial issues. Pre-service science teachers need to experience this tension in their science teacher training programs in order to cause changes in the learning process. Freire (1998) pointed out that the necessary procedure to transform ingenuous into critical curiosity should be accompanied by a rigorous ethical formation side by side with an aesthetic appreciation. Beauty and decency, hand in hand.

Most of the students' first reading of the poem indicated that they took spontaneous and common-sense standpoints. On the other hand, to think in a scientific way is to engage in methodological rigor that characterizes the epistemological curiosity of reflecting subjects (Freire, 1998). Racism is institutionalized, and it is also underpinned by the sociohistorical exclusion of ethnic minority groups from scientific knowledge in Western societies. The authentic dialogue cannot ignore the students' perceptions. At the same time, a dialogical stance should stress the tension and highlight the different understandings based on science views.

The right thinking assumes great relevance in terms of racism, considering the existence of a substantial body of research showing that teachers have lower expectations for ethnic minority students (Archer, 2008; Brandon, 2003; Liou \& Rojas, 2018). Teachers' unconscious stereotypes and lower expectations directly affect black students' development at schools. For example, beyond underrepresentation, studies demonstrate significant differences in undergraduate student ratings of teaching effectiveness based on the instructor's race (Hamermesh \& Parker, 2005; Smith \& Hawkins, 2011).

Hence, to educate on ethnic and racial relations is to move educators and students into an environment that needs to be explored. This will usually put agents involved into conflict situations, since knowledge will be created through confronting historical, sociocultural and sociopolitical point of views. A fundamental feature of the professor's stance is to be persuasive. In other words, the professor needs to convince the students of the reasonableness of scientific view. This is a total experience that is simultaneously directive, political, pedagogical, aesthetic and ethical. For this, teacher support, in the form of beliefs about students' academic abilities, is crucial (Cherng, 2017; Liou \& Rojas, 2018). In this experience, beauty, decent and seriousness walks along together. There can be no "right thinking" disconnected from ethical principles (Freire, 1998). For this reason, professors need to acknowledge social discrepancies and historical process of marginalization allowing thereby no neutral teaching practices.

\subsection{Episode 4 - Enlarging points of view}

In the final part of the discussion, the goal was to furnish scientific, historical and social elements capable of supporting the interpretation attributed to the poem and to reflect on specific aspects of science education. The episode was divided into two parts. The first addressed social characteristics related to racism and discrimination, while the second referred to aspect of these questions from a science viewpoint.

The professor's first sentence was "why are we discussing this?" This is an important structural strategy for thematic development, named metadiscourse. It is used to comment on or explain aspects of the explored content itself. The episode was the longest one (22'47') because statistical data were presented. The discourse almost exclusively came from the Professor (15'47' against 3'09" of students' contributions), with the aim of enlarging standpoints by 
means of facts, statistical data and other arguments. The students demonstrated some degree of mental fatigue, probably because of the activity duration and intensity of the debate. Longer periods of silence were more common, and the students usually talked in chorus, in agreement with some Professor's affirmations.

1. Professor: But why are we discussing this? You know, even though in Brazil there is a relatively high black population - it's around 50\% - black people are a minority in public universities and in higher-paid occupations. Why is this so? Have you ever thought about it?

2. Student A: Few opportunities to study.

3. Professor: Why are there few opportunities to study? (something inaudible).

4. Professor: When we talk about lack of opportunity to study, it is fundamental to understand the historical process clearly. We need to do a historical analysis on this. For example, do you know when black people started studying at schools?

5. Some students: No.

6. Professor: Do you know that slavery was abolished in Brazil in 1888? That's more than 120 years ago. Do you know what happened after it was abolished? Where did black people use to live? Where did black people use to work with? The abolition of slavery went something like this: all right, you do not want to work here anymore, so you can go, but without a house, without food, without a job, without healthcare systems and, obviously, without schools. The main preoccupation was to survive under such conditions. They had no home, they had no social service. So, where could they start to live? Far away from the center. The first favelas were constructed at that time. Why do you think that most people who live in favelas or slums are black people? It is directly associated with our history. Do you know how many black people finish high school and how many go to public universities?

7. Some students: No.

8. Professor: Around 13\% of the black people get high education in Brazil, whereas $26 \%$ of white people go to university. Statistically, whites have twice more chance. Would you like to know one more thing? Samba. What are samba singers called?

9. Some students: Tricksters. Vagabonds.

10. Professor: Right. Why? Because samba was strongly influenced by African descendants. Where did they used to live? Remember, slavery was abolished in 1888. The boom period of samba was around 1920-1930. These people lived in slums. So, they were called vagabonds. People said that they did not like to work, but just to sing samba. Historical situations like that have continued. For instance, during nursery education, for little blond girls, their teachers interact physically, making bows in their hair. But the teachers do not touch young black girls.

11. Student C: That was a long time ago.

12. Professor: Not just in past times. I read a recent paper that depicted such results. An investigator stayed at a school for some months to examine the relationships between teachers and children.

13. Student D: I think this only happened in a few schools.

14. Professor: I do not think so. This has occurred many times, in different environments and for a long time.

15. Student O: Professor, this is common. At the school where I work, I've seen this.

16. Professor: That's right. But we have to be careful about this. In addition to social issues, our country is marked fundamentally by great discrimination against black and against indigenous people. You have probably heard this statement: Ah! Brazil is a mixed-race country. Do you know why they launched this myth of miscegenation?

17. Student E: To reduce the number of blacks.

18. Professor: Because a country composed of blacks could not develop, could not grow. So, this myth of miscegenation was created to say: "No, Brazilian people are not black, because the population is a mixture of black and white. So, people became mulatto, brown-skinned and other terms, but not black. Black became synonyms of a bad thing.

Figure 5. Transcription of the episode 4: Enlarging points of view: Part I - Socio-historical aspects.

This episode was largely non-interactive and authoritative. The teacher established a confirmatory interaction bringing out the apparent racism presented in Brazil, considering that some students had rejected racism as the theme of the poem, and had perceived racism as existing only in isolated cases.

Use of a narrative is another aspect of this episode that stands out. As a logical argument, a narrative is also a rhetorical structure that aims to provide evidence for systematic expression of a thematic pattern (Lemke, 1990). Thus, thematic items are interconnected in loops, such that some items are joined to many others to achieve a 
conclusion. A narrative tends to proceed chronologically. It tells of a sequence of events and aims to reach a climax or a result.

This can be interpreted regarding the use of scientific rhetorical semantics. The science language may be distinctive, primarily but not exclusively on reason of its semantics, which are partly developed through rhetorical structures that reinforce some specific figures of speech, and partly through the moves of an activity structure.

Thus, the professor introduced some Eurocentric, white, male and Christian aspects that have been present in the development of science, along with the need to seek other knowledge of African and Latin American origins. Those ways of seeing and transforming the world are underestimated in traditional curricula as practices aiming towards breaking down the unilateral vision of science. Freire (1998, p. 40) argued that teachers needed to take a solid theoretical position: "Teachers engaged in right thinking, which is that is a way of being and not just an occasional phase, need to take an attitude of seriousness in seeking a secure and solid basis for their positions".

Presentation of historical and statistical information relating to these issues is mentioned by Francisco Junior (2008) as an important step towards unmasking the racism that has been instilled in society. The molecular structure of living beings, which is basically composed of the same 20 amino acids and five nitrogenous bases, independently of the living being, was discussed in this regard. Verrangia and Silva (2010) defend approaches based on exploring diversity through the natural sciences, highlighting, at the same time, the biological equality of all beings as one valid way to overcome stereotypes and place value on ethnic and racial diversity. The same authors also drew attention to the need to look critically at the development of science for the purpose of avoiding underestimation of knowledge arising from Africa, as well as contextualizing ethnic-racial issues in the classroom.

In physics classes, for example, Rifkin (2016) describes discussions on demography imbalances with a view to promote better outcomes for underrepresented students, an approach which would benefit all students engaged on the activity. In the work, the author also describes the students' research about work of non-white physicists, widening the students' comprehension about scientists.

Interactions with different points of view and with the distinct characteristics of Brazilian multiculturalism are pointed out by Silva (2010) as a central element of education on ethnic-racial relations. According to the author (2010, p. 77), "Education on ethnic-racial relations is processed at the core of different sociopolitical perspectives, in comparison between different points of view originated from different cultural and historical roots".

Atwater, Butler, Freeman \& Parsons (2013) suggested that prepare science teachers for multicultural education is to set the challenge of grappling with racial, ethnic, cultural, instructional and curricular issues and with what science teaching means in the education process. The goal is to transform the structure of educational institutions such that they promote educational equality for all students. Nevertheless, this challenge is increasingly hard, considering the white cultural predominance within educational institutions and the obstacles that need to be overcome (Atwater et al., 2013; Marque et al., 2018). Therefore, pre-service science candidates usually find themselves in situations after situations in which there are no conflicts on what they think in terms of racism. As a consequence, their beliefs cannot be changed.

This was corroborated by student D's belief (turn no. 13: I think this only happened in a few schools). Regardless of all the data, student D remained comprehending racism as occasional situations. From this perspective, understanding the social and historical construction of black inferiority has an important function. Although the schooling process by itself cannot change social conditions, questioning the supposed benefits from race miscegenation and debating inequalities is a promising step towards a critical view.

Although this last episode presented predominantly authoritative characteristics, the students' opinions could also be perceived to amplify the point of view (turn no. 15: Professor, this is common. At the school where I work, I've seen this). At the same time, one of the teaching aims is to develop a critical view about black people in Brazil. A study by Mortimer and Scott (2003) indicates that achieving a balance between authoritative and dialogic approaches can keep students and their ideas within the discussions.

This was observed when student $\mathrm{O}$ (who had not previously participated in the discussion) presented an argument in opposition to student D. Accordingly, this experience shared by Student O may have helped other participants to understand black people's struggles. Their white colleagues need to understand these issues, so that practices enhancing the teaching environment for blacks can be implemented. Through greater diversity of viewpoints, learners can become involved in different ways of thinking. According to Freire (1998), in a true learning environment, learners need to be authentic subjects of the construction and reconstruction of what is being taught, side by side with their partners (colleagues and teachers). In Freire's view, only through this way people can speak authentically about the knowledge that is taught, such that the very essence of it is grasped.

The second part of the discussion was dedicated to inquire the students about their initial impressions and empirical perceptions, using as an example a drawing of a beaker containing a transparent "liquid" made on a 
whiteboard. Indeed, an aqueous solution of sodium bicarbonate was used as well, in order to foster notions on the nature of science (such as the one that experiments are not the only route to knowledge, uncertainties exist within science) and the role of creativity. This scenario can provide resources for teaching students about science. Scientific knowledge is formed through human actions. Empirical evidences are important but do not suffice for building scientific knowledge in the means that intuition and creativity are important components at this process.

This confrontation between representation and reality is also important in science teaching (molecules models are really like these representations). As well as a poem requires interpretation, scientific models/symbols also demand it as well, which is not free but guided by theories. The learning of the role of models and representations is fundamental in science teaching.

1. Professor: We cannot say for sure what it is (the purpose of the poem). Can anybody tell what this is for sure? (professor shows a beaker that contained a sodium bicarbonate solution).

2. Student D: A liquid.

3. Professor: A liquid!

4. Student C: It is for sure.

5. Professor: Are you sure about this? What sort of liquid?

6. Student H: We cannot know.

7. Professor: We could investigate, but we could never see the molecules. Can you imagine molecules into this liquid?

8. Student M: Can we consider it to be water?

9. Professor: You can assume that.

10. Student L: By means of the representations of the hydrogen (...) which would have the formula $\mathrm{H}_{2} \mathrm{O}$. As a liquid, the molecules would be separated from each other.

11. Student C: In motion.

12. Professor: That's important. Molecules are not static. What would keep water in the liquid phase?

13. Unknown student: Interactions.

14. Student L: Hydrogen interactions.

15. Professor: What do you know about this?

16. Student L: It is something that keeps molecules together.

17. Student J: Intermolecular forces.

18. Professor: Water molecules present electric dipoles, and because of it they (molecules) can attract each other.

There is an electrostatic interaction between opposite charges on water molecules. How do you know this?

19. Student L: We imagine it.

20. Student C: From models.

21. Student J: Representations.

22. Professor: Now, I ask you. Do you wonder whether molecules are really like these representations?

23. Student J: Not really.

24. Professor: So, what we do in imagining those questions in poetry is similar to the work developed in science. We will never get to see the water molecules, but we can think about them. We imagine them, and we represent them. Art and science use representations of reality. We use symbols to represent things that we cannot see. So, the exercise in poetry analysis is, in some way, similar to that of science. More importantly, teaching science is teaching people to think like scientists, in other words, to think in terms of models and theories. Discussing the poem is to try to think like the poet. But we are never absolutely sure about what was the author's real message. Like in science, we are never absolutely sure. There is no absolute certainty in science. So, there is one more point. The substance in that beaker isn't a liquid: it's an aqueous solution. A sodium bicarbonate solution.

Figure 6. Transcription of the episode 4 - Enlarging points of view: Part II - Scientific aspects

Hunter (2010) outlines the importance of researchers in different areas of knowledge to reconsider practices of representation shared between art and science. Under this perspective, the mental analysis of the "liquid" contained into the beaker is a kind of representation of the tear's analysis described in the poem. It is necessary to broaden the nuances related to the construction of scientific knowledge. In regard to science education, some authors have stated possibilities for the dialogue between science and other forms of knowledge over time, as well as the dialectic relation between science and the social-cultural context in which the theories are built (Chakravartty, 2010; Galili, 2011; Guerra $\&$ Braga, 2012). In this sense, exploring some scientific tools (hypothesis formation, experiment design, statistical analysis, knowledge communication), in order to learn about science itself while eroding the stereotype that certain groups do not do science, has been useful (Rifkin, 2016). 
These considerations guided the construction of the debate. Its aim was not to provide a definitive answer regarding the meaning of the poem or the identity of the solution in the beaker. From a dialogical point of view, the proposal was to create an atmosphere in the audience that would stimulate these students to think and to enlarge their view about dialogue, imagination and representation, and how these can be useful for taking a critical stance regarding social issues; in this case, about racism. At the same time, the discussion made it possible to link in some issues related to chemistry.

\section{Some implications}

The main goal of this study was to examine how a debate can foster pre-service teachers' skills regarding social issues about racism. There were limitations relating to the methods and sampling used. Dialogical educational experiences require more time to be effective. Accordingly, the effectiveness of this debate for transforming students' conceptions was lower. The lengths of time for which each student spoke during the debate differed and some of them did not shared their thoughts along the activity. Also, the words spoken cannot be taken to represent a generalization of the participants' ideas. Moreover, the words of one teacher regarding multicultural education do not properly embody all the challenges in this realm, as well as the sample used did not fully represent the needs for chemistry teacher training at the university investigated.

Although isolated activities are not enough to consistently develop teacher's beliefs and attitudes against racism, the findings suggest that discursive movements can encourage critical thinking about it. Starting from dialogical discourse, the debate was led gradually to the debate of the poem's important aspects, which allowed appropriation of meanings even by those who had not identified the issue initially. This seemed to be directly related to lack of questioning of the issue in formal education, which thus revealed how racism has become naturalized and institutionalized within society. The results show that the communicative approach adopted had benefits regarding engagement of the students in the discussion on ethnocultural differences, with the intention of breaking through discriminatory actions.

Education can only change oppressive situations through transforming people's interactions with other members of the global community onto paths grounded on social justice. The purpose of attaining this within teacher training programs is obstructed by the lack of diversity at universities and schools. Prospective teachers have little opportunity to interact with teaching staff members of color because of the historical white predominance in these institutions.

In this regard, science education plays a pivotal role. Pedagogical approaches need to be reconceptualized in terms of curriculum, course content, evaluations, relationships and other issues, taking into consideration multiple and diverse perceptions of racism. Even when teachers think that they are putting equality into practice through their pedagogic action, deficient thinking is still embedded in the deep structures that shape their attitudes. In this regard, Buck and Quigley (2013), for example, claim that research on science education needs to explore intersections of even greater complexity. Racism and dialogical perspectives are among these complex intersections. Likewise, educating on ethnic and racial relations consists of moving educators and students into an environment that needs to be explored.

In this sense, dialogical moments create opportunities to discuss and to improve a responsively multicultural education. Future researches may explore tensions within dialogue, evidenced on the debate's first moments when different interpretations on the poem's themes emerged. The learning and the transformation of social actions come from the difference of the viewpoints, for this reason pedagogical approaches should embrace the diversity of perceptions.

To break away from these deep-rooted problems within teacher training, science teachers need to undergo a continuous system of cultural training and professional development that includes, among other things: i) comprehension regarding the impossibility of both neutral education and neutral science; ii) critical analysis on real social equity, the living conditions of minorities and the values of different cultural perspectives; and iii) real experiences of dialogical practices. Those aspects provide opportunities for future teachers to rethink their approaches towards diversity and pedagogy and need to be regularly discussed in teacher training, in order to foster continual engagement that can reveal and modifying discriminatory situations.

\section{Acknowledgment}

We would like to gratefully acknowledge the helpful of colleagues and friends who made the activity reported on this paper possible by video-recording it (Diego Eufrásio, Eduardo Pereira and Jailson Gilberto), performing the musicalized poem (Cícero Vasconcelos) or attending the invitation for the debate. We also acknowledge the FNDE/SESU/MEC for scholarship. 


\section{Biographical note}

Wilmo Ernesto Francisco Junior has an undergraduate degree and a PhD in chemistry education (São Paulo State University). Currently, Wilmo is an adjunct professor of chemistry education at the Federal University of Alagoas (Brazil) in undergraduate and postgraduate course. His main research interests lie in science and technology teaching and learning, science history and philosophy, science teacher education and ICT use in science education.

Erasmo Moises dos Santos Silva has an undergraduate degree in chemistry education (Federal University of Alagoas, Brazil) and a master's degree in Science (University of São Paulo, Brazil). Erasmo works as a high school chemistry teacher in a state school of Mato Grosso, Brazil, developing studies on ICT use in science education, arts in science education and public politics on education.

\section{References}

Aguiar, O. G., Mortimer, E. F., \& Scott, P. (2009). Learning from and responding to students' questions: The authoritative and dialogic tension. Journal of Research in Science Teaching, 47(2), 174-193. doi:10.1002/tea.20315

Ambe, E. B. (2006). Fostering multicultural appreciation in pre-service teachers through multicultural curricular transformation. Teaching and Teacher Education, 22(6), 690-699. doi:10.1016/j.tate.2006.03.005

Andrews, G. R. (1992). Black political protest in Sao Paulo, 1888-1988. Journal of Latin American Studies, 24(1), 147-71. doi:10.1017/S0022216X00022987

Andrews, G. R. (2009). Afro-Latin America: Five questions. Latin American and Caribbean Ethnic Studies, 4(2), 191210. doi:10.1080/17442220902920119

Ani, M. (2007). Yurugu: An Afrikan-centered critique of European cultural thought and behavior. Washington, DC: Nkonimfo.

Archer, L. (2008). The impossibility of minority ethnic educational "success"? An examination of the discourses of teachers and pupils in British secondary schools. European Educational Research Journal, 7(1), 89-107. doi:10.2304/eerj.2008.7.1.89

Atwater, M. M., Butler, M. B., Freeman, T. B., \& Parsons, E. C. (2013). An examination of black science teacher educators' experiences with multicultural education, equity, and social justice. Journal of Science Teacher Education, 24(8), 1293-1313. doi:10.1007/s10972-013-9358-8

Bicak, L. J., \& Bicak, C. J. (1988). Scientific method: Historical and contemporary perspectives. The American Biology Teacher, 50(6), 348-353. doi: $10.2307 / 4448760$

Bogdan, R., \& Biklen, S. K. (1998). Qualitative research in education: An introduction to theory and methods. Boston, MA: Allyn \& Bacon.

Brandon, W. W. (2003). Toward a White teachers' guide to playing fair: Exploring the cultural politics of multicultural teaching. Qualitative Studies in Education, 16(1), 31-50. doi:10.1080/0951839032000033518

Brickhouse, N. W., \& Potter, J. T. (2001). Young women's scientific identity formation in an urban context. Journal of Research in Science Teaching, 38(8), 965-980. doi:10.1002/tea.1041

Buck, G. A., \& Quigley, C. F. (2013). Allowing our research on urban, low-SES, African American girls and science education to actively and continually rewrite itself. In J. A. Bianchini, V. L. Akerson, A. C. Barton, O. Lee, \& A. J. Rodriguez (Eds.), Moving the equity agenda forward: Equity research, practice, and policy in science education (pp. 173-190). Dordrecht, Netherlands: Springer.

Byker, E. J., \& Marquardt, S. K. (2016). Using critical cosmopolitanism to globally situate: Multicultural education in teacher preparation courses. Journal of Social Studies Education Research, 7(2), 30-50.

Cerqueira, D. R. C., \& Moura, R. L. (2014). Lives lost and racism in Brazil (In Portuguese). Publicatio UEPG Ciências Sociais Aplicadas, 22(1), 73-90. doi:10.5212/PublicatioCi.Soc.v.22i1.0007

Chakravartty, A. (2010). Truth and representation in science: two inspirations from art. in R. Frigg \& M. Hunter (Eds.), Beyond mimesis and convention: Representation of art and science (pp. 33-50). Dordrecht, Netherlands: Springer.

Cherng, H. Y. S. (2017). If they think I can: Teacher bias and youth of color expectations and achievement. Social Science Research, 66, 170-186. doi:10.1016/j.ssresearch.2017.04.001

Delpit, L. (1995). Other people's children: Cultural conflict in the classroom. New York, NY: New Press.

Francisco Junior, W. E. (2008). Anti-racism education: Reflections on the possible contribution of science teaching and of some thinkers (In Portuguese). Ciência \& Educação, 14(3), 397-416. doi:10.1590/S151673132008000300003

Freire, P. (1998). Pedagogy of freedom: Ethics, democracy, and civic courage. Lanham, MD: Rowman \& Littlefield Publishers. 
Freire, P. (2005a). Pedagogy of the tolerance (In Portuguese). São Paulo, Brazil: UNESP.

Freire, P. (2005b). Pedagogy of the oppressed: 30th anniversary edition. London, England: The Continuum International Publishing.

Freyre, G. (1951). Brazil: An interpretation. New York, NY: Alfred Knopf.

Galili, I. (2011). Promotion of content cultural knowledge through the use of the history and philosophy of science. Science \& Education, 21(9), 1283-1316. doi10.1007/s11191-011-9376-x

Galili, I. (2013). On the power of fine arts pictorial imagery on science education. Science \& Education, 22(8), 19111938. doi:10.1007/s11191-013-9593-6

Gillborn, D. (2001). Racism, policy and the (mis)education of black children. In R. Major (Ed.), Educating our black children: New directions and radical approaches (pp. 13-27). London, England: Routledge Falmer.

Graham, R. (1999). Free African Brazilians and the state in slavery times. In M. Hanchard (Ed.), Racial politics in contemporary Brazil (pp. 30-58). Durham, NC: Duke University Press.

Guerra, A., \& Braga, M. (2014). The name of the rose: A path to discuss the birth of modern science. Science \& Education, 23(3), 643-654. doi:10.1007/s11191-012-9543-8

James, W. Y. (2019). Imprint of Racism: White Adult Males' Transformational Experience from Racial Antipathy to Racial Reconciliation. American Journal of Qualitative Research, 3(1), 93-116. https://doi.org/10.29333/ajqr/5813

Hamermesh, D., \& Parker, A. (2005). Beauty in the classroom: Instructors' pulchritude and putative pedagogical productivity. Economics of Education Review, 24 (369-376). doi:10.1016/j.econedurev.2004.07.013

Hanchard, M. (1994). Black Cinderella? Race and the public sphere in Brazil. Public Culture, 7(1), 165-185. doi:10.1215/08992363-7-1-165

Hasenbalg, C. (1985). Race and socioeconomic inequalities in Brazil. In F. Pierre-Michel (Ed.), Race, class and power in Brazil (pp. 25-41). Los Angeles, CA: Center for Afro-American Studies, University of California.

Hasenbalg, C., \& Valle Silva, N. (1999). Notes on racial and political inequality in Brazil. In M. Hanchard (Ed.), Racial politics in contemporary Brazil (pp. 154-178). Durham, NC: Duke University Press.

Hunter, M. C. (2010). Experiment, theory, representation: Robert Hooke's material models. In R. Frigg \& M. Hunter (Eds.), Beyond mimesis and convention: Representation of art and science (pp. 193-292). Dordrecht, Netherlands: Springer.

Ianni, O. (1972). Race and class in Latin America. In A. Richmond (Ed.), Readings in race and ethnic relations (pp. 237-56), Oxford, England: Pergamon.

Johnson, C., \& Hinton, H. (2019). Toward a Brillant Diversity. Journal of Culture and Values in Education, 2(1), 5670. Retrieved from http://cultureandvalues.org/index.php/JCV/article/view/27

Kagema, J. (2018). The School Curriculum and Its Influence on Teacher Motivation in Curriculum Implementation in Kenya. Journal of Culture and Values in Education,1(1), 9-25. Retrieved from http://cultureandvalues.org/index.php/JCV/article/view/3

Kishimoto, K. (2016). Anti-racist pedagogy: From faculty's self-reflection to organizing within and beyond the classroom. Race Ethnicity and Education, 21(4), 540-554. doi:10.1080/13613324.2016.1248824

Ladson-Billings, G. (2014). Culturally relevant pedagogy 2.0: Aka the remix. Harvard Educational Review 84(1), 7484. doi:10.17763/haer.84.1.p2rj131485484751

Lemke, J. L. (1990). Talking science: Language, learning, and values. Norwood, NJ: Arblex Publishing Corporation.

Lewis, T. E. (2016). "But I'm not a racist!" Phenomenology, racism, and the body schema in White, pre-service teacher education. Race Ethnicity and Education, 21(1), 118-131. doi:10.1080/13613324.2016.1195354

Liou, D, D., \& Rojas, L. (2018). The significance of the racial contract in teachers' college expectancies for students of color. Race Ethnicity and Education. doi:10.1080/13613324.2018.1511529

Malone, K. R., \& Barabino, G. (2009). Narrations of race in STEM research settings: Identity formation and its discontents. Science Education, 93(3), 485-510. doi:10.1002/sce.20307

Marom, L. (2018). Under the cloak of professionalism: Covert racism in teacher education. Race Ethnicity and Education, 22(1), 1-19. doi:10.1080/13613324.2018.1468748

Márque, J., Peña, C., Jones, L., Orange, A., \& Simieou, F. (2018). Academic success and resiliency factors: A case study of unaccompanied immigrant children. American Journal of Qualitative Research, 2(1), 162-181.

Mitran, I. I. (2017). Indigenous Heraldry: Transferring ethnic imagery from the mundane to the canonical. Journal of Ethnic and Cultural Studies, 4(1), 26-33.

Mortimer, E. F., \& Scott, P. H. (2003). Meaning making in secondary science classrooms. Buckingham, England: Open University Press/McGraw Hill. 
O’Loughlin, M. (1992). Engaging teachers in emancipator knowledge construction. Journal of Teacher Education, 43, 336-346. doi:10.1177/0022487192043005003

Rifkin, M. (2016). Addressing underrepresentation: Physics teaching for all. The Physics Teacher, 54(2), $72-74$. doi:10.1119/1.4940167

Santos, A. O., Schucman, L. V., \& Martins, H. V. (2012). Brief history of Brazilian psychological thinking about ethnic/racial relationships (In Portuguese). Psicologia: Ciência e Profissão, 32(special number), 166-175. doi:10.1590/S1414-98932012000500012

Silva, C. S. (2011). Poetry from António Gedeão and chemistry teacher education (In Portuguese). Química Nova na Escola, 33(2), 77-84. Retrieved from http://qnesc.sbq.org.br/online/qnesc33_2/02-EA10309.pdf

Silva, E. M., \& Francisco Junior, W. E. (2018). Art in education for ethnical-racial questions: A dialog with chemistry teaching. Química Nova na Escola 40(2), 79-88. doi:10.21577/0104-8899.20160108

Silva, P. G. (2011). Education on ethnic-racial relations from the perspective of Afrodescendants: Agenda for knowledge production. Interamerican Journal of Educational Research, 4(1), 63-86. Retrieved from https://scholarworks.iu.edu/journals/index.php/ried/article/view/1962

Smith, B. P., \& Hawkins, B. (2011). Examining student evaluations of black college faculty: Does race matter? Journal of Negro Education, 80(2), 149-162. Retrieved from https://www.jstor.org/stable/ 41341117?seq=1\# page_scan_tab_contents

Tarman, B. (2012). Effective leadership in culturally diverse schools. Energy Education Science and Technology Part B: Social and Educational Studies, 4(2), 1103-1114.

Theodoro, M., \& Jaccoud, L. (2005). Race and education: Limitations from universalist policies (In Portuguese). In S. A. Santos (Ed.), Affirmative actions and struggle against racism in Americas (In Portuguese) (pp. 113-119). Brasília, Brazil: MEC-SECAD.

Valente, R. R. (2017). The vicious circle: Effects of race and class on university entrance in Brazil. Race Ethnicity and Education, 20(6), 851-864. doi:10.1080/13613324.2016.1150824

Verrangia, D., \& Silva, P. G. (2010). Citizenship, ethnical-racial relationships and education: Challenges and opportunities in the teaching of sciences (In Portuguese). Education and Research, 36(3), 705-718. doi:10.1590/S1517-97022010000300004

Wade, P. (2010). Race and ethnicity in Latin America (2nd ed.). New York, NY: Pluto Press. 